\title{
KUFER PELEN WSPOMNIEŃ: (AUTO)BIOGRAFICZNE PODEJŚCIE DO DZIEDZICTWA
}

Stowa KLUCzowe: archeologia nas samych, dziedzictwo, materialność, pamięć, rzeczy KEYwORDs: the archaeology of us, heritage, materiality, memory, things

\section{WSTĘP: WSZYSCY JESTEŚMY TERAZ ARCHEOLOGAMI}

Archeologia już od jakiegoś czasu nie jest jedynie nauką odtwarzającą najdawniejsze dzieje człowieka na podstawie jego materialnych pozostałości (Olsen $i$ in. 2012). Coraz więcej archeologów, badaczy rzekomo tej odległej przeszłości (prahistorii), analizuje materialne relikty, które powstały w XIX, XX, a nawet w XXI w. (por. Buchli, Lucas 2001; Holtorf, Piccini 2009; Olsen, Pétursdóttir 2014; w kontekście polskiej archeologii por. Kola 2000; Głosek 2010; Ławrynowicz, Żelazko 2015; Zalewska 2016). Uprawianie archeologii ukierunkowanej na rzeczy z niedawnej przeszłości proponuję w tym tekście.

Michael Shanks idzie w jednej ze swoich prac nawet krok dalej. W książce pod tytułem The archaeological imagination argumentuje, iż ,wszyscy jesteśmy teraz archeologami” (Shanks 2012; por. Holtorf 2005). W tym miejscu trzeba być bardzo precyzyjnym. Rzecz jasna, twierdzenia M. Shanksa nie można czytać dosłownie: zaledwie niewielka część społeczeństwa ukończyła studia archeologiczne. Tylko specjalista potrafi rozpoznać fragment prahistorycznej ceramiki, nie każdy dostrzeże w niepozornym kamieniu element pękniętego żarna obrotowego; w końcu, potrzeba sporego doświadczenia i odpowiedniej wiedzy by w krajobrazie zauważyć zniszczony przez orkę kurhan itd. Zatem z innym rodzajem archeologii mamy tutaj do czynienia.

Dla M. Shanksa archeologia jest - by tak to ująć - ucieleśnieniem pewnej specyficznej wyobraźni, którą określa on mianem archeologicznej (archaeological imagination). Pisząc o niej brytyjski badacz ma na myśli pewien zbiór tropów i metafor, zainteresowania ruinami oraz kulturą materialną czasów minio- 
nych; przekonanie, iż na podstawie rzeczy można poznać przeszłość. Między innymi te elementy przyczyniły się do powstania w drugiej połowie XIX wieku archeologii jako nauki akademickiej (Thomas 2004; Trigger 2006). Podzielając składowe tegoż imaginarium stajemy się wszyscy (do pewnego stopnia) badaczami rzeczy starych i nowych (ryc. 1). Słowem, uprawianie archeologii nie sprowadza się do murów akademickich. To wręcz pewien sposób myślenia, postrzegania i doświadczania otaczającego świata.

Powszechność owej kulturowej fascynacji wynikającej z odkrywania i doświadczania materialnych pozostałości (z) przeszłości jest argumentem za postulatem, iż „wszyscy jesteśmy teraz archeologami”. Czas, materialność, rozkład, poznawanie ukrytej, także za kolejnymi warstwami ziemi, przeszłości; zainteresowanie reliktami czasów minionych pozostają u samego sedna takiej archeologicznej wrażliwości i wyobraźni. Jak zauważa M. Shanks (2012: 25; thumaczenie autora):

By odtworzyć świat znajdujący się za ruinami, by wskrzeszać do życia ludzi ukrytych w kawałku antycznej ceramiki, fragment przeszłości: to jest praca archeologicznej wyobraźni, kreatywny impuls i zdolność będące u podstawy archeologii, lecz również impuls zanurzony w wielu kulturowych predyspozycjach, dyskursach i instytucjach, zwykle łączonych z nowoczesnością. Archeologiczna wyobraźnia jest zakorzeniona we wrażliwości, wszechobecnym zbiorze postaw wobec śladów i pozostałości, wobec pamięci, czasu i temporalności. Właśnie to jest budulcem historii.

Odkrycie kufra widocznego na rycinie 1 stanowi przyczynek do dyskusji nad archeologicznym wymiarem niedawnej przeszłości. W pierwszej części tego artykułu omawiam krótko archeologię jako sposób badania rzeczy bez względu na czas ich powstania; jako praktykę zawsze osadzoną „tu i teraz”. Następnie, podejście teoretyczne zwane „biografią rzeczy” jest użyte jako rama interpretacyjna do refleksji nad rolą, znaczeniem i funkcjonowaniem we współczesnych kontekstach XX-wiecznego dziedzictwa. Kolejny wątek wywodu omawia dzieje kufra w celu wyeksponowania biograficznego i relacyjnego charakteru kultury materialnej. Ostatnia część tekstu to refleksja nad podejściem do archeologicznych artefaktów, skupiającym się głównie na ich ochronie i zarządzaniu. Tutaj stawiam główną tezę artykułu, iż czasem niszczenie i przemijanie dziedzictwa jest w istocie jego częścią; elementem powstawania nowych i niepowtarzalnych reliktów niedawnej przeszłości. Innymi słowy, niekiedy im mniej ochrony i zarządzania dziedzictwem tym lepiej dla niego samego. 

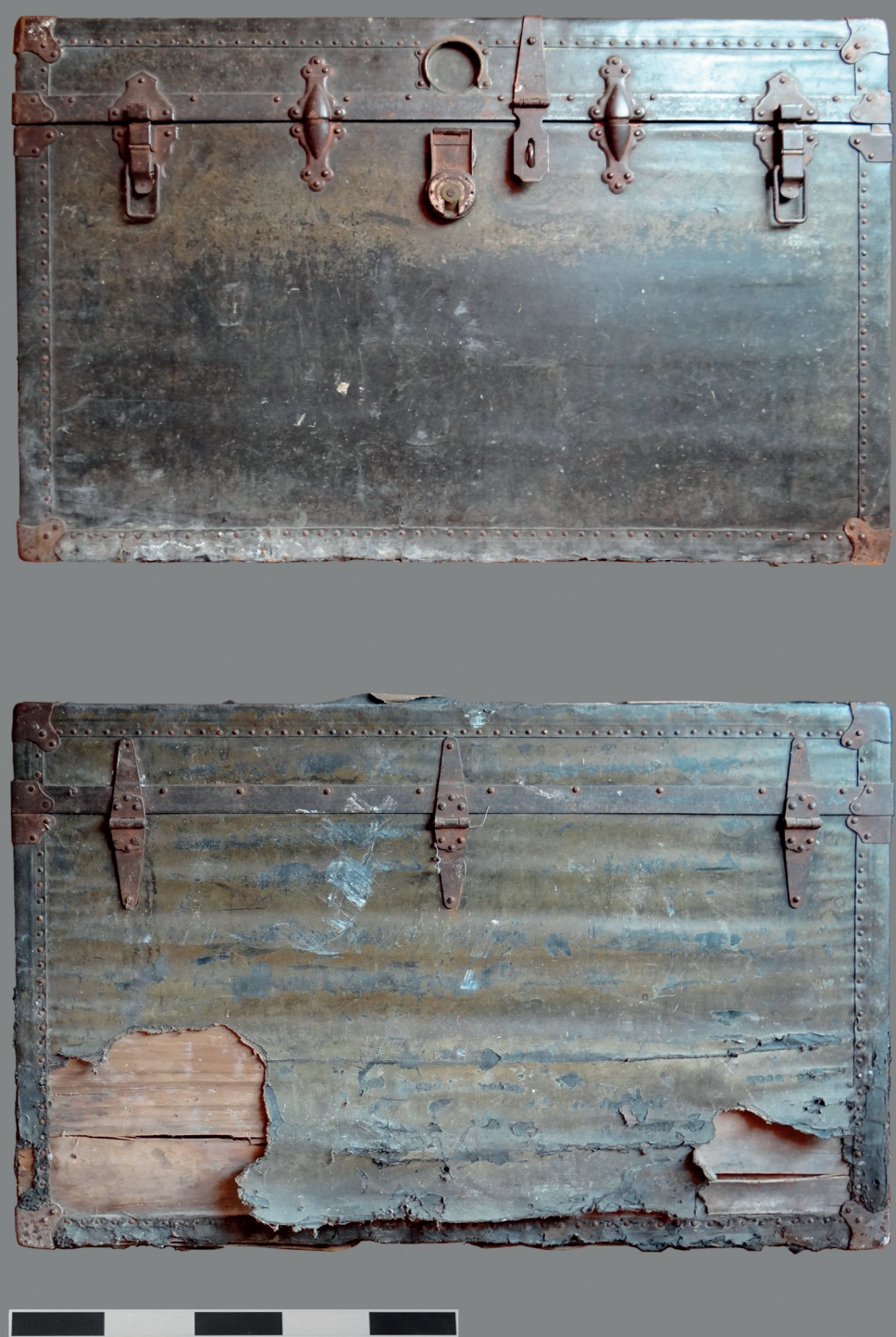

Ryc. 1. „Archeologiczna wyobraźnia”: niespełna 100-letni kufer jako „archeologiczny” artefakt (fot. D. Kobiałka). 


\section{ARCHEOLOGIA ,TU I TERAZ”: KUFER JAKO (,ARCHEOLOGICZNE”) DZIEDZICTWO}

W pracy pod tytułem Modern material culture: The archaeology of us pod redakcją Richarda A. Goulda i Michaela B. Schiffera (1981) argumentowano, iż archeologia może być sposobem badania szeroko rozumianej współczesności. Rzecz jasna, ci autorzy nie pierwsi jako archeolodzy odwoływali się do współczesności. Zwykle jednak archeologiczne odniesienia do teraźniejszości (np. analogia etnograficzna) były lepszymi lub gorszymi sposobami interpretowania pozostałości z odległej przeszłości (por. Prinke 1973). Modern material culture zakładała coś zgoła odmiennego: archeologia wraz ze swoją metodyką badawczą, zainteresowaniem kulturą materialną, relacjami jakie łączą ludzi i rzeczy może być ważnym głosem w rozumieniu otaczającego nas świata (por. González-Ruibal 2014). Stąd też amerykańscy badacze takie podejście określili mianem ,archeologii nas samych" (the archaeology of us). Rzeczy, których używamy każdego dnia są częścią archeologii „tu i teraz”, przykładem specyficznego „dziedzictwa archeologicznego". Oczywiście, w takich samych kategoriach coraz częściej traktuje się pozostałości XX-wiecznych konfliktów zbrojnych (np. Saunders 2007; Moshenska 2013; Kobiałka i in. 2015).

Można powiedzieć, iż o I czy też II wojnie światowej myśli się zwykle jako już odległej, minionej przeszłości. Ich relikty to przecież eksponaty wielu muzeów. Niemniej jednak, były one wydarzeniami globalnymi, które dotknęły - w taki czy inny sposób - większość z naszych rodziców, dziadków, czy też pradziadków. Fakt ten daje sposobność do uprawiania całkiem dosłownie ,archeologii nas samych". Przeszukując zakamarki na strychu, czy też w piwnicy, rozmawiając z osobami, które przeżyły II wojnę światową można natknąc się na pozorne, fragmentaryczne, „nagryzione przez ząb czasu” artefakty, dokumenty i wspomnienia. Są one niezwykle ciekawym przykładem, tego jak wielka historia łączy się z mikrohistoriami konkretnych ludzi, czasem własnych rodzin (por. Domańska 1999).

Tacy naukowcy jak Hein Bjerck (2014) czy Cornelius Holtorf (2014) dowodzą nawet, iż perspektywa personalna jest jednym z kluczowych podejść badawczych $w$ archeologii. W tym ujęciu przedmiotem badawczym jest rodzinne dziedzictwo: losy, materialne relikty, efemeryczne wspomnienia itd. związane z własną rodziną (rodzicami, dziadkami, pradziadkami). Taka rama interpretacyjna pozwala na budowanie niezwykle interesujących i wielowątkowych narracji. Jest to wręcz forma eksperymentu na skraju nauki i powieściopisarstwa. Jeden z kilku takich przykładów wiąże się z badaniami Jonny Ulin (2009), która przeprowadziła prace wykopaliskowe na reliktach domu swojej babci na północy Szwecji. Tropem nauki uwzględniającej - by tak powiedzieć - „archeologiczność" własnego kontekstu kulturowo-historycznego podążam w tym artykule (ryc. 2). 


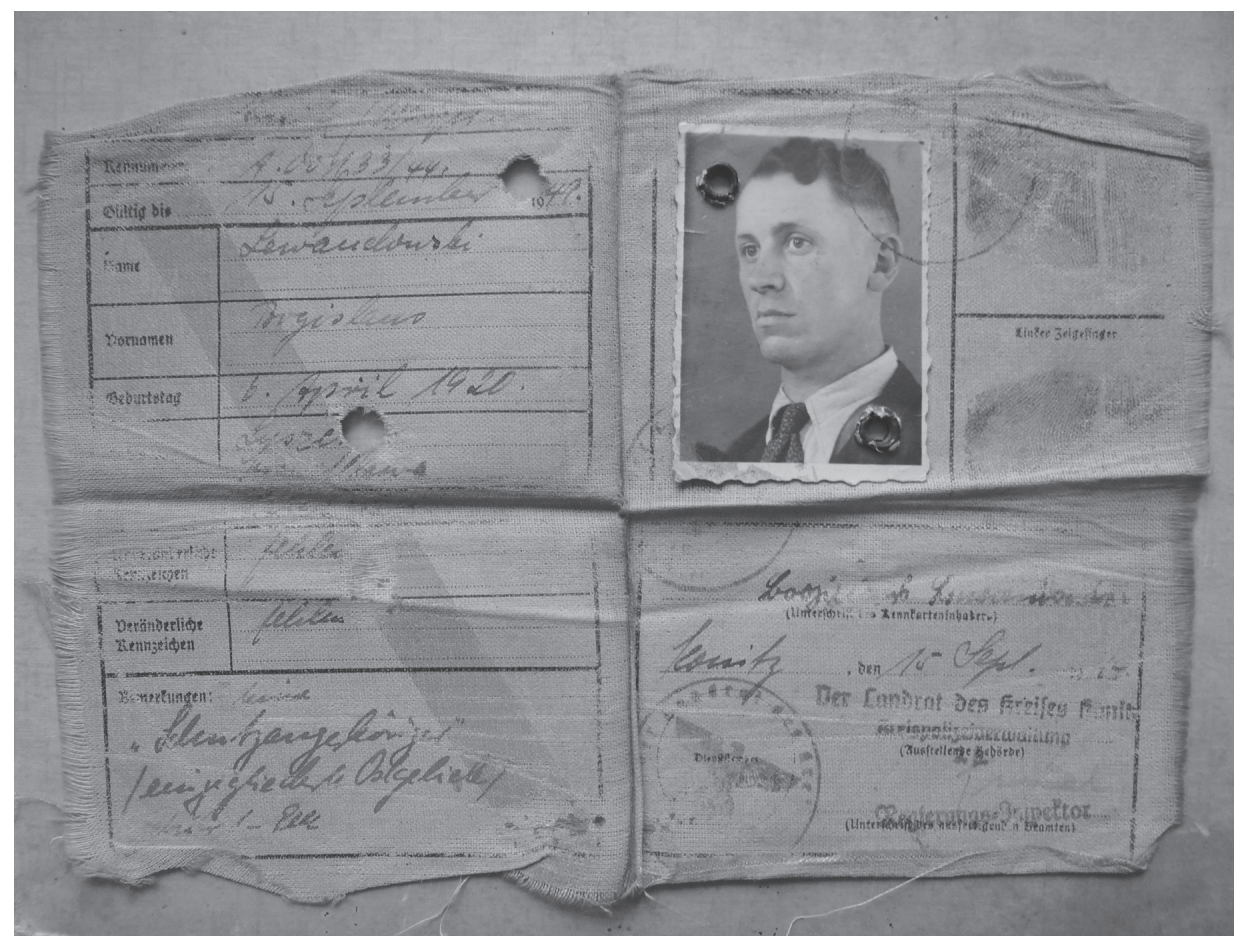

Ryc. 2. Dziedzictwo drugowojenne: Kennkarte mojego dziadka znaleziona w kufrze (fot. D. Kobiałka).

Na początku lutego 2016 r. postanowiłem wybrać się w odwiedziny do babci. Celem wizyty było spisanie jej niezwykle bogatych, złożonych i wielowątkowych wspomnień (ryc. 3). W trakcie rozmowy okazało się, iż babcia posiada jeszcze kufer przywieziony przez jej ojca ze Stanów Zjednoczonych w 1919 r. (por. ryc. 1). Opowieść o kufrze, który jeszcze tego samego dnia „odkopałem” w piwnicy, jego losy, to jak był częścią życia mojej babci i jej najbliższej rodziny może stanowić interesujący przyczynek do dyskusji nad rolą, znaczeniem i funkcjonowaniem we współczesnych kontekstach XX-wiecznego dziedzictwa. Mówiąc inaczej, kufer jest częścią biografii mojej babci, a ona sama, jej rodzina, moja osoba są elementami biografii tego przedmiotu. W rzeczy samej, zarówno o ludziach, jak i o przedmiotach i miejscach można myśleć z perspektywy biograficznej; mówiąc właściwiej, poprzez „kulturową biografię rzeczy” (Kopytoff 2005). 


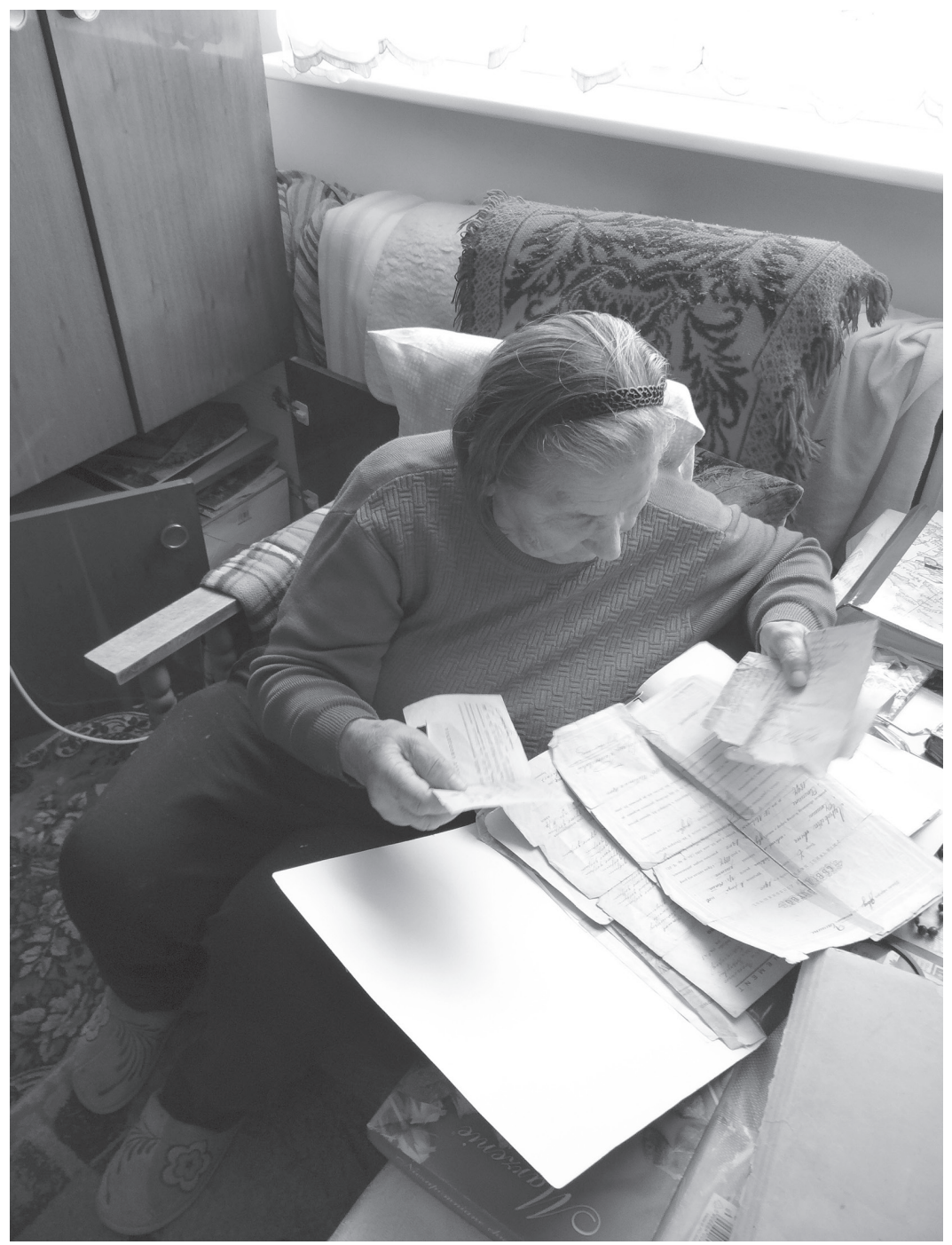

Ryc. 3. „Kopiąc w dokumentach i wspomnieniach”: Hanna Gostomska w trakcie „archeologii nas samych” (fot. D. Kobiałka).

\section{Kulturowa BIOGRAFIA RZECZY}

Ostatnie lata XX oraz pierwsza dekada XXI w. w archeologii to czas, kiedy wielu badaczy pisało o kulturowej biografii rzeczy i miejsc. Megality, kurhany, naczynia ceramiczne itd. miały mieć swoje złożone, wielowątkowe, czasem wielowiekowe historie życia (np. Shanks 1998; Jones 2002; Darvill 2006). Podej- 
ście to zakłada, iż można myśleć o artefaktach w kategoriach dynamicznych, jako element i wynik procesów społecznych i kulturowych (Kopytoff 2005). Również w przypadku polskiej archeologii ukazało się kilka prac przedstawiających potencjał interpretacyjny biografii rzeczy jako sposobu analizy materialnych pozostałości oraz całych krajobrazów kulturowych (np. Domańska 2006; Kobiałka 2008; 2015; Kobyliński 2014). Z tego też powodu zasygnalizuję tu jedynie kilka kluczowych elementów biografii rzeczy jako sposobu myślenia o rzeczach i miejscach.

Słowem, rzeczy mają kulturowe historie (u-)życia (biografie). W swoim głośnym eseju Igor Kopytoff (2005: 252) jasno stwierdza:

Pracując nad biografią jakiejś rzeczy, można stawiać pytania podobne do tych, jakie stawiamy, pytając o ludzi. Jakie są z socjologicznego punktu widzenia możliwości biograficzne, które pociągają za sobą jej „status”, czas, w którym istnieje, i kultura, do której należy? W jaki sposób możliwości te się realizują? Jak wyglądała dotąd jej kariera i co ludzie uważają za idealny ,życiorys” dla takiej właśnie rzeczy? Czy rzeczy bywają w „różnym wieku”, jakie są etapy ich życia i jak wyglądają ich kulturowe wyznaczniki? Jak zmienia się wraz z wiekiem rzeczy jej użycie i co dzieje się z nią, kiedy przestaje być użyteczna?

Takie podejście do kultury materialnej okazało się bardzo przydatne z perspektywy archeologicznej. Pozwoliło ono budować wielowątkowe i różnorodne narracje, które można opowiedzieć o rzeczach, ludziach i miejscach. Jak dalej pisze amerykański antropolog kulturowy (Kopytoff 2005: 253):

Oczywiście czysto materialna biografia samochodu różni się dość znacznie od jego biografii technicznej, zwanej przez fachowców opisem stanu technicznego. Samochód może też mieć życiorys ekonomiczny, obejmujący jego wartość początkową, ceny sprzedaży i odsprzedaży, procent spadku jego wartości, reakcję jego ceny na recesję, zestawienie kosztów utrzymania wozu na przestrzeni kilku lat. Ma on też kilka biografii społecznych: jedna z nich może się koncentrować na ekonomicznym wymiarze samochodu dla rodziny jego właściciela; w innej historię jego własności można powiązać ze strukturą społeczną i podziałem na klasy [...].

Dwie konsekwencje pisania kulturowych biografii rzeczy i miejsc należy uznać za szczególnie ważne. Po pierwsze, archeolodzy zaakceptowali różnorodność interpretacji danych prahistorycznych monumentów za część ich historii i element biografii. Tutaj bardzo ważny był artykuł Nico Roymansa (1995) na temat kurhanów i cmentarzysk kultury urn popielnicowych. N. Roymans uznał lokalne opowieści o m.in. trollach i czarownicach rzekomo zamieszkujących pomiędzy kurhanami za element biografii danego miejsca.

Druga konsekwencja wynika z pierwszej: zaczęto bliżej przyglądać się współczesnym losom artefaktów archeologicznych jako także ważnym elemen- 
tom ich długiego trwania (por. Kobiałka 2008). Artykuł C. Holtorfa (2002) jest doskonałym tego przykładem, gdzie opisywane są losy pewnego niepozornego fragmentu naczynia ceramicznego wydobytego w trakcie wykopalisk na Sycylii. Niemieckiego badacza nie interesuje technologia wypału tego konkretnego zabytku, ewentualne jego funkcje i znaczenia w pierwotnym kontekście społeczno-kulturowym itd. C. Holtorf analizuje prahistoryczny artefakt od momentu jego odkrycia do chwili, aż skorupa ceramiczna została zdeponowana w magazynie muzealnym. Te elementy również są częścią historii długiego życia większości wydobywanych w trakcie prac terenowych artefaktów. Jak twierdzi C. Holtorf (2002: 49; thumaczenie autora): ,[...] materialne tożsamości przypisywane rzeczom nie są ich esencjalnymi właściwościami ale wynikiem specyficznych relacji między ludźmi i rzeczami”. Ujmując to jeszcze inaczej, biografia rzeczy daje ramy interpretacyjne do dyskusji nad „procesualnością” dziedzictwa jako takiego. Dzieje kufra są doskonałym przykładem tego jak rzeczy i ludzie współtworzą siebie nawzajem.

\section{KuFER: BIOGRAFICZNOŚĆ I RELACYJNOŚĆ DZIEDZICTWA}

Jest 14 marca 2016 r.: w tym momencie kufer (por. ryc. 1) znajduje się w jednym z mieszkań przy ulicy Rzepakowej w Chojnicach, woj. pomorskie. Przedmiot jawi się jako stary i zniszczony - statyczna rzecz pozbawiona funkcji i znaczeń. Jednak w większości przypadków dziedzictwo to wypadkowa tego, co materialne i tego, co społeczne. To nie tylko przedmiot wykonany z drewna, obity skórą, wzmocniony i udekorowany metalowymi elementami. Ta rzekoma pasywna rzecz to zarówno suma procesów: biografii pewnych ludzi, przedmiotów i miejsc. Jak to słusznie zauważa Rodney Harrison (2013: 217; tłumaczenie autora):

Dziedzictwo nie jest światem obrazów i tekstów, lecz fundamentalnym rodzajem doświadczenia materialnego (i siłą rzeczy, społecznego) świata [...]. Dziedzictwo nie jest zapisaniem znaczenia na niezapelnionych przedmiotach, miejscach i praktykach, które powstają w wyniku procesu, lecz zamiast tego jest ono tworzone jako rezultat materialnych i społecznych możliwości, lub też „afordancji”, kolektywów ludzkich i nie-ludzkich agentów, materialnych i niematerialnych istot, w świecie. Nie jest ono przede wszystkim intelektualnym przedsięwzięciem, czymś co istnieje tylko w ludzkim umyśle, ale jest tym, co pojawia się w wyniku dialogu, czy też praktyk ludzi i rzeczy.

To, co materialne i to, co społeczne nadal tworzy biografię tego konkretnego kufra. Wielka historia i mikrohistorie przenikają się w dziejach tego niepozornego przedmiotu. Kilka epizodów z jego historii życia omówię poniżej. 


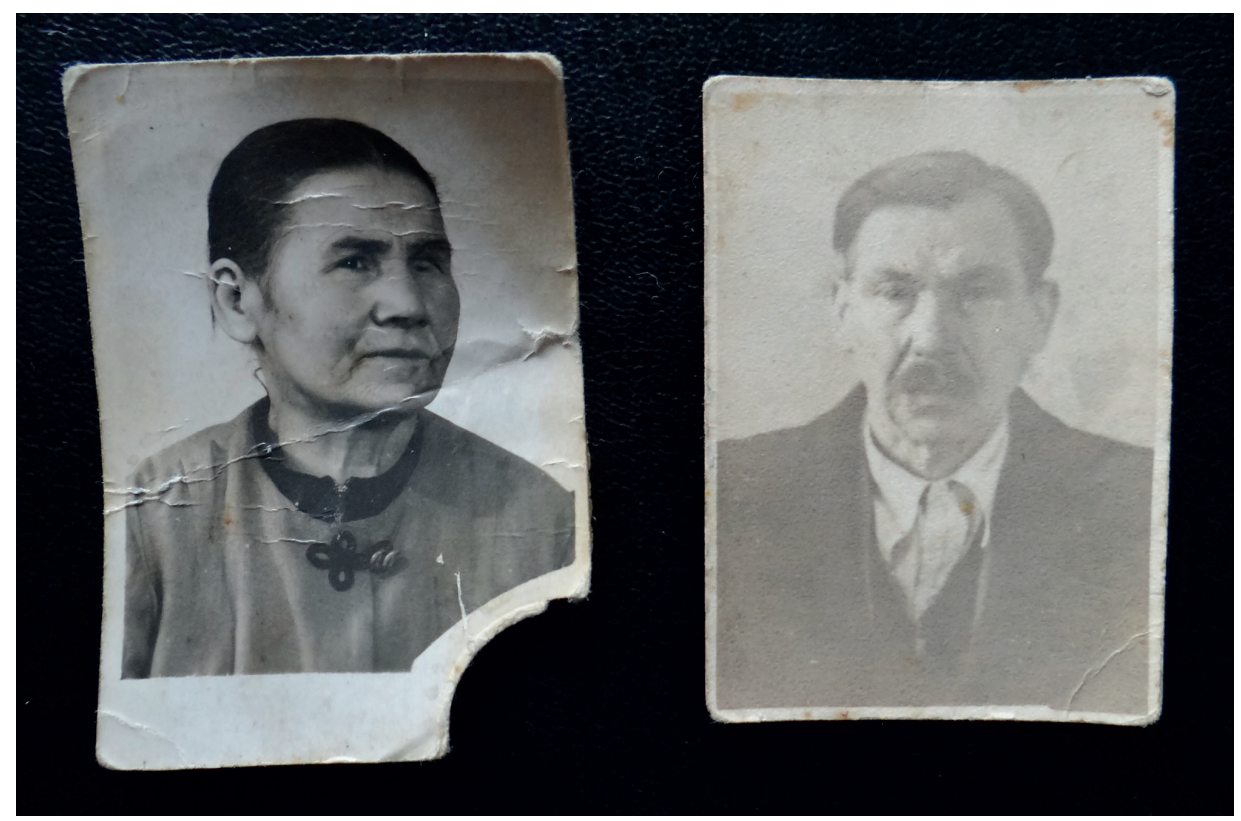

Ryc. 4. Anna i Michał Kudlikowie (archiwum prywatne).

Moja rodzina od strony matki pochodzi z Galicji, części dawnego zaboru austriackiego (ryc. 4). Początek XX w. to czas, kiedy wielu chłopów z Galicji emigrowało do Stanów Zjednoczonych w poszukiwaniu pracy. Tak też było w przypadku mojego pradziadka Michała, który z synem i grupą kilku znajomych z wioski Brzozowiec (dzisiejszy powiat sanocki, woj. podkarpackie) wybrał się dwukrotnie do Ameryki. Pracowali oni w kopalniach na wschodnim wybrzeżu Stanów w niezwykle trudnych warunkach. Jedyną, zachowaną do dnia dzisiejszego w rodzinie pamiątką po pradziadku jest wspominany kufer.

Wielka Wojna spotkała pradziadka w trakcie pobytu w Stanach Zjednoczonych. Wraz z przyjaciółmi postanowił przeczekać czas zawieruchy wojennej pracując w kopalni. Do Brzozowca wrócił dopiero w 1919 r. Jedną z rzeczy przywiezionych zza oceanu był podróżny kufer. Został on wykonany przez $\mathrm{Al}$ fred Friend Trunk Company, zakład który miał swoją siedzibę w Petersburgu, w stanie Virginia (wschodnie wybrzeże Stanów Zjednoczonych) (ryc. 5). Można przypuszczać, iż pradziadek - jak wspomina babcia - „nie harował jak wół w kopalni”" by przywieźć do Polski ekskluzywny kufer. W rzeczy samej, styli-

\footnotetext{
${ }^{1}$ Wypowiedzi w cudzysłowach jeśli nie oznaczono tego osobnym odniesieniem bibliograficznym, to cytaty z rozmowy z Hanną Gostomską, którą przeprowadziłem 5 marca 2016 r.
} 


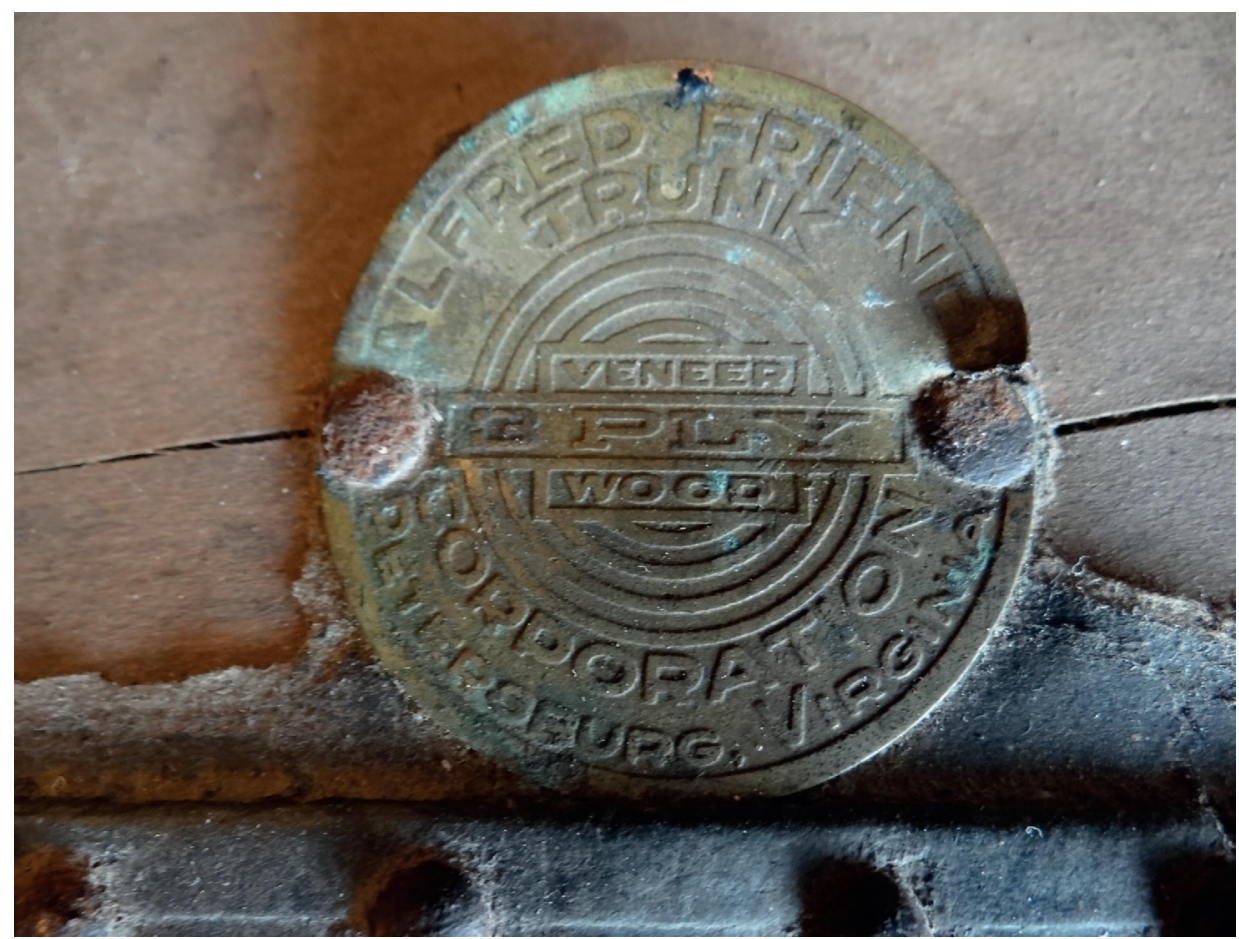

Ryc. 5. Znak firmowy Alfred Friend Trunk Company (fot. D. Kobiałka).

styka okuć jest bardzo charakterystyczna dla tego typu przedmiotów wykonywanych na przełomie lat 20. XX w. w USA. Petersburg był lokalnym centrum przemysłu drzewnego ${ }^{2}$. W związku z faktem, iż okolice miasta były obszarami silnie zalesionymi, w Petersburgu i najbliższym jego otoczeniu miały swoje siedziby zakłady oraz różne firmy związane z obróbką drewna. Jednym z takich rzemieślników był Alfred Friend, którego zakład działał krótko w latach 20. XX w. Tak też, zupełnie typowy kufer przebył drogę morską ze wschodniego wybrzeża Stanów Zjednoczonych do portu w Bremie (Niemcy). Stamtąd zapewne koleją pradziadek dojechał do Krakowa i następnie Sanoka; do Brzozowca było już niespełna $20 \mathrm{~km}$. Po powrocie do domu, kufer stał się częścią wyposażenia drewnianej chaty. Był również miejscem - co ważne w kontekście dalszej biografii - deponowania dokumentów rodzinnych.

Według babci, Brzozowiec, jak i jej rodzina nie ucierpiały dotkliwie w trakcie II wojny światowej, chociaż „,pociski latały”. To czerwonoarmiści okazali się znacznie niebezpieczniejsi dla lokalnej społeczności niż wojska Wehrmachtu.

\footnotetext{
${ }^{2}$ Korespondencja e-mailowa z Marvinem Millerem z 15 lutego 2016 r.
} 
Tych pierwszych nazywano „ruchańcami”, z wiadomych powodów... W trakcie naszej rozmowy słowo to z ust babci padło kilkukrotnie. Najtrudniejsze dni dla rodziny miały dopiero nadejść.

Wraz z przejściem czerwonoarmistów lokalna społeczność próbowała wrócić do codziennego trybu życia. Jedną z pierwszych rzeczy było uporządkowanie „dziedzictwa wojennego". Babcia opowiadała, jak własnoręcznie musiała zbierać z rodzinnego pola szczątki majora niemieckiego: „ręka była w jednym miejscu, noga gdzie indziej".

29 marca 1946 r. cały Brzozowiec został podpalony przez Wojsko Polskie pod pretekstem pomagania „banderowcom”. Spalono również dom rodzinny babci. Przed zaprószeniem ognia wojskowy zażądał „papierów od ojca”. „Papiery", wśród nich dokumenty z czasów pracy pradziadka w kopalni oraz ostatnie pieniądze, które rodzinie pozostały z tego okresu, zostały zabrane przez dowódcę. Mieszkańcy wioski nawet nie mieli czasu na spakowanie najpotrzebniejszych rzeczy. $Z$ domu babci udało się jedynie uratować pierzyny, poduszki i właśnie kufer, który babcia wraz z matką własnoręcznie wyciągnęły z płonącego już domostwa: „chwilę potem płonący sufit runął na ziemię”. Kufer był niezwykle cenny ponieważ w jego wnętrzu były zdeponowane wszystkie dokumenty rodzinne, $\mathrm{w}$ tym akty własności ziemi, akty chrztów, adresy do rodziny, czy też świadectwa szkolne (ryc. 6).

Niedługo potem zaczęły się wywózki na wschód. Rodzina babci szczęśliwym zbiegiem okoliczności dowiedziała się wcześniej o tym fakcie. Przez ponad tydzień chowali się w lesie; kufer $\mathrm{z}$ dokumentami został również ukryty w krzakach. Całe dnie leżeli pod starą zwaloną sosną, w nocy szukali pożywienia. „Do Brzozowca nie było sensu wracać, było to też niebezpieczne”. Pradziadek postanowił wykopać ziemiankę na skraju lasu. W takich ekstremalnych warunkach rodzina mojej babci mieszkała ponad rok. Ziemianka miała okno, żeliwny piecyk, który przyniesiono z dawnego domu; ściany pomieszczenia zostały nawet udekorowane przez babcię i siostry. Kufer stał się częścią nowego lokum: służył za schowek, stół, a w nocy za łóżko dla jednej z sióstr babci. Ziemianka była za mała dla całej rodziny: „z siostrą spałyśmy, aż do pierwszych śniegów pod stogiem siana".

Następne przesiedlenia miały miejsce już w 1947 r. Wojsko Polskie natrafiło na ziemiankę babci przez przypadek, kiedy unosił się dym z komina. Jedyną rzeczą, którą rodzina mogła zabrać był kufer i to, co do niego udało się zapakować. Następnie przewieziono ich, wraz z wieloma innymi Polakami, w wagonach bydlęcych do Szczawnego, gdzie ponad tydzień czekali na kolejne transporty ludzi. Ostatecznie zostali wywiezieni, aż do Miastka, skąd wozami i na pieszo rodzina babci trafiła do niewielkiej poniemieckiej wioski Cetyń (Zettin), dzisiejszy powiat bytowski, woj. pomorskie. Kufer cały czas wędrował z rodziną. W Cetyniu babcia spotkała swojego przyszłego męża (ryc. 7). 


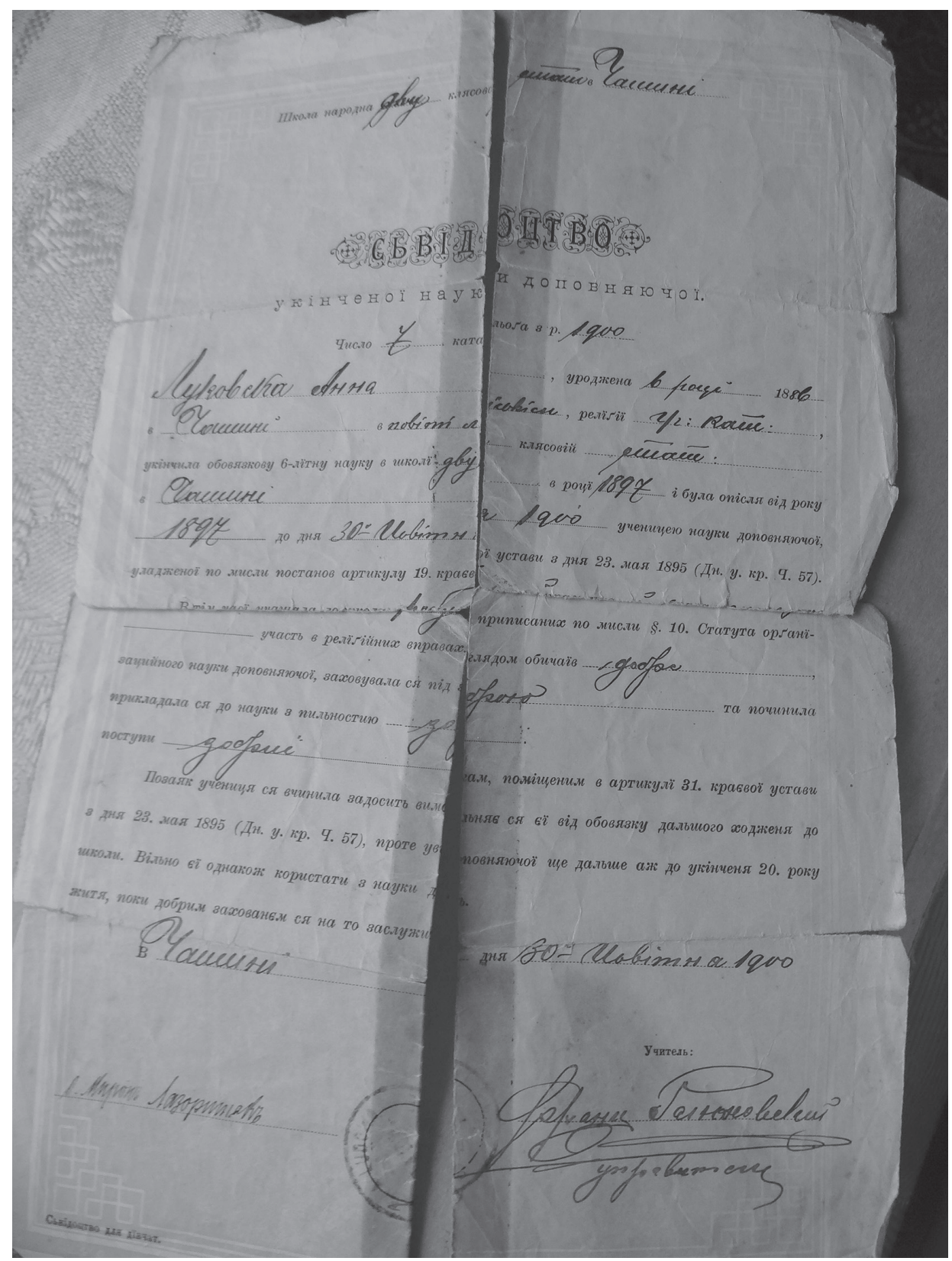

Ryc. 6. Świadectwo szkolne mojej prababci z 1900 r., które schowane było w kufrze i tym sposobem nie zostało spalone w 1946 r. (fot. D. Kobiałka). 


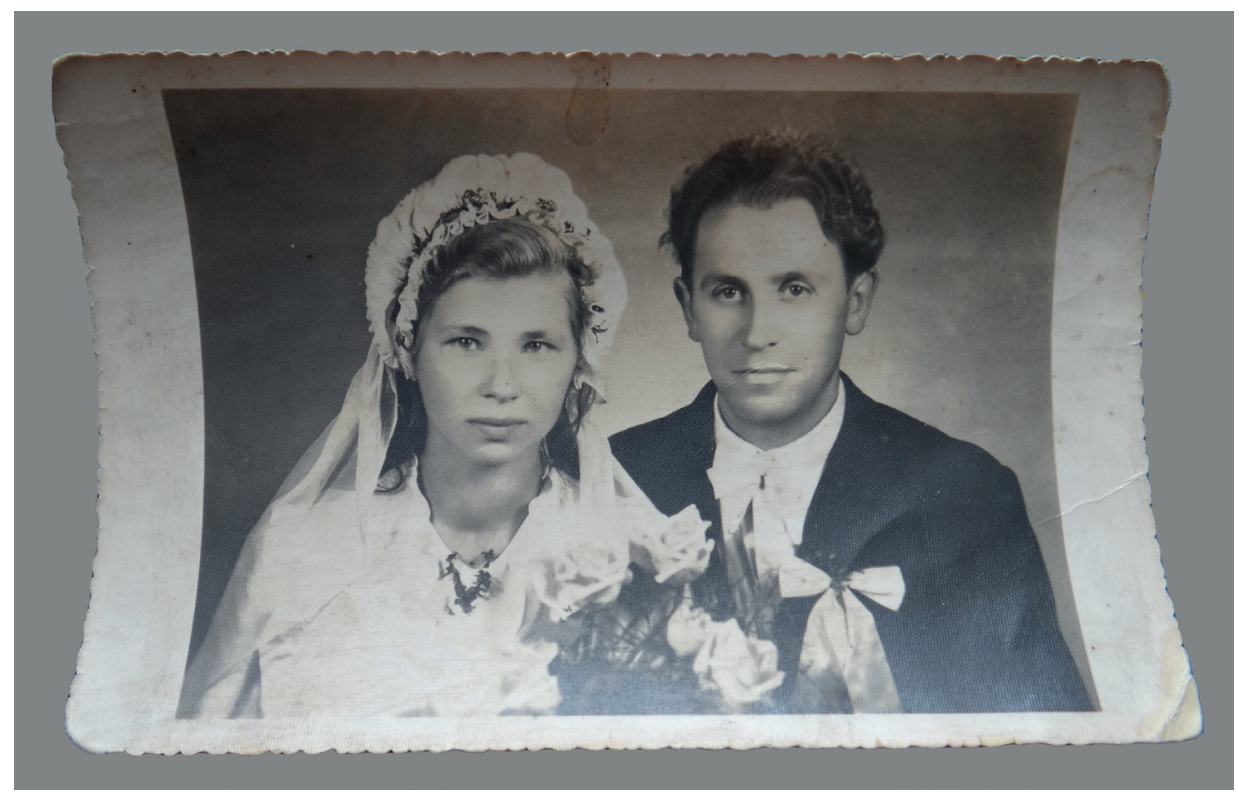

Ryc. 7. Hanna i Bogusław Gostomscy (fot. D. Kobiałka).

Ostatniego marca 1973 r. babcia z dziadkiem i dziećmi, między innymi z moją mamą, przeprowadzili się do Ogorzelin, dzisiejszy powiat chojnicki, woj. pomorskie. Wtedy też kufer został zniesiony do piwnicy, gdzie służył jako schowek na starą i nieużywaną babciną garderobę. Tam też zalegał, aż do 4 marca 2016 r., kiedy go odkryłem.

Jak wynika ze skrótowo opisanej biografii, dzieje kufra są złożone i wielowątkowe. Wiele miejsc, ludzi, rzeczy i wspomnień przenika się w nim. Są jednak wydarzenia, których babcia nie pamięta, a które - można powiedzieć - „zapamiętane są" przez sam kufer. Chodzi tutaj o „materialne wspomnienia” (material memories) (por. Olivier 2011) (ryc. 8).

Rycina 8 przedstawia zbliżenie na front kufra. Zwykle takie przedmioty miały symetrycznie rozmieszczone klamry, zatrzaski i sam szyfr. Jednak egzemplarz pradziadka odbiega od tego wzorca. $Z$ tego powodu początkowo miałem spory problem z odnalezieniem analogii. Posiada on bowiem dodatkowy zawias służący do zamykania kufra na kłódkę. Nity w tym miejscu są zupełnie inne niż w pozostałych częściach kufra; są one w rzeczywistości wkrętami, które posłużyły do przymocowania zawiasu. To sugeruje, że został on dodany później. Kiedy, kto i gdzie to wykonał? Tego niestety babcia już nie była w stanie powiedzieć. Warto również zauważyć, iż pod zawiasem widoczne są wytarcia na powierzchni skóry, które pozostawiła ocierająca się kłódka. 


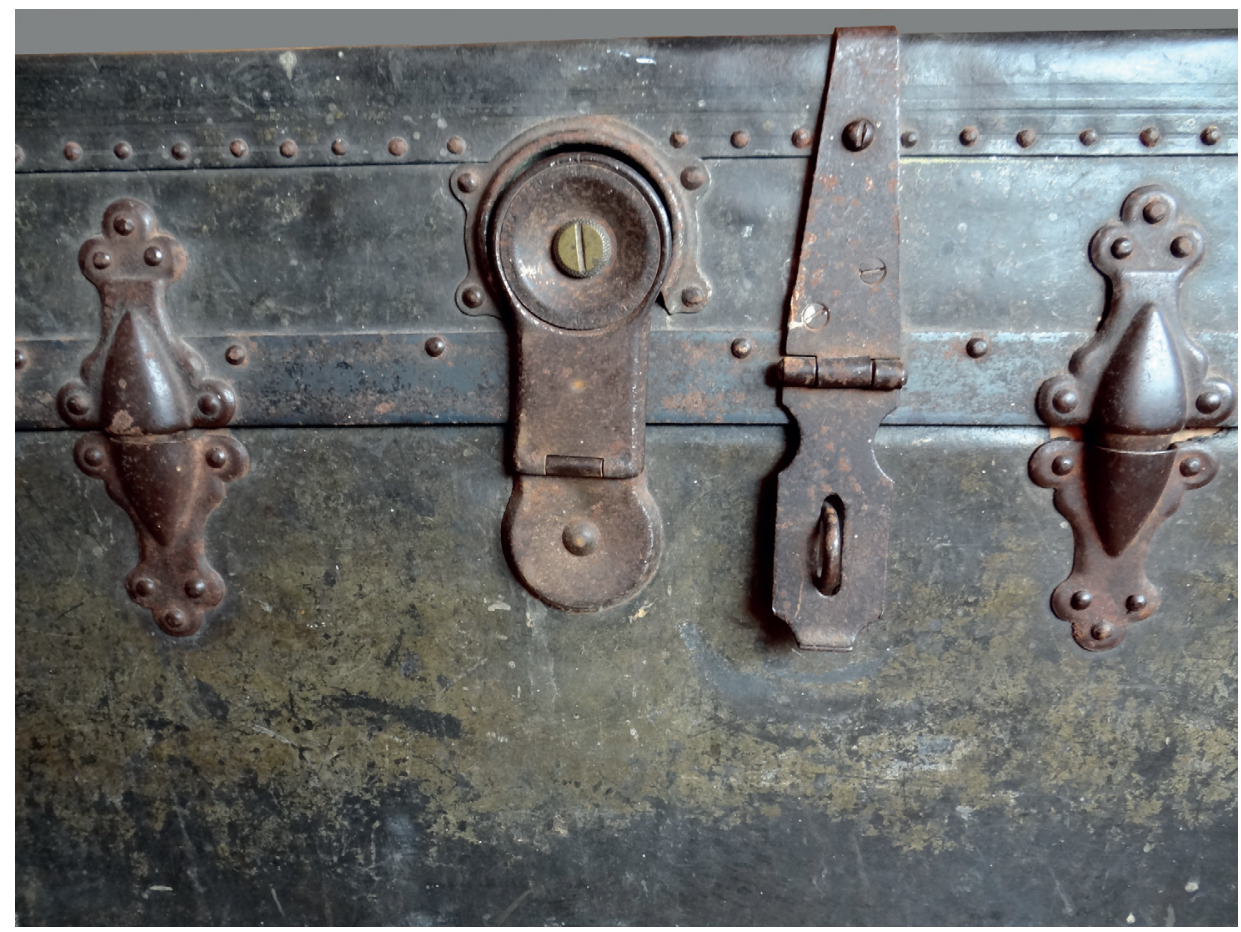

Ryc. 8. Zbliżenie na front kufra (fot. D. Kobiałka).

Upływ niespełna 100 lat odcisnął piętno na kufrze. Skóra odkształciła się, straciła swój pierwotny kolor i strukturę, pokryła się patyną. Liczne zadrapania, otarcia, ubytki skóry tworzą - można powiedzieć - „aurę” tego przedmiotu, która doskonale wpisuje się w Benjaminowskie rozumienie tego pojęcia jako „osobliwa pajęczyna przestrzeni i czasu: niepowtarzalne zjawisko pewnej dali, choćby była najbliżej" (Benjamin 1975: 37). Właśnie owe braki, zniszczenia, odkształcenia konstytuują kufer jako „niepowtarzalne dziedzictwo".

Ryciny 9 i 10 ukazują te (materialne) wspomnienia z biografii kufra, o których babcia nie wie lub też - co znacznie mniej prawdopodobne - nie pamięta. To, co społeczne, to, co materialne współtworzy dane dziedzictwo. 


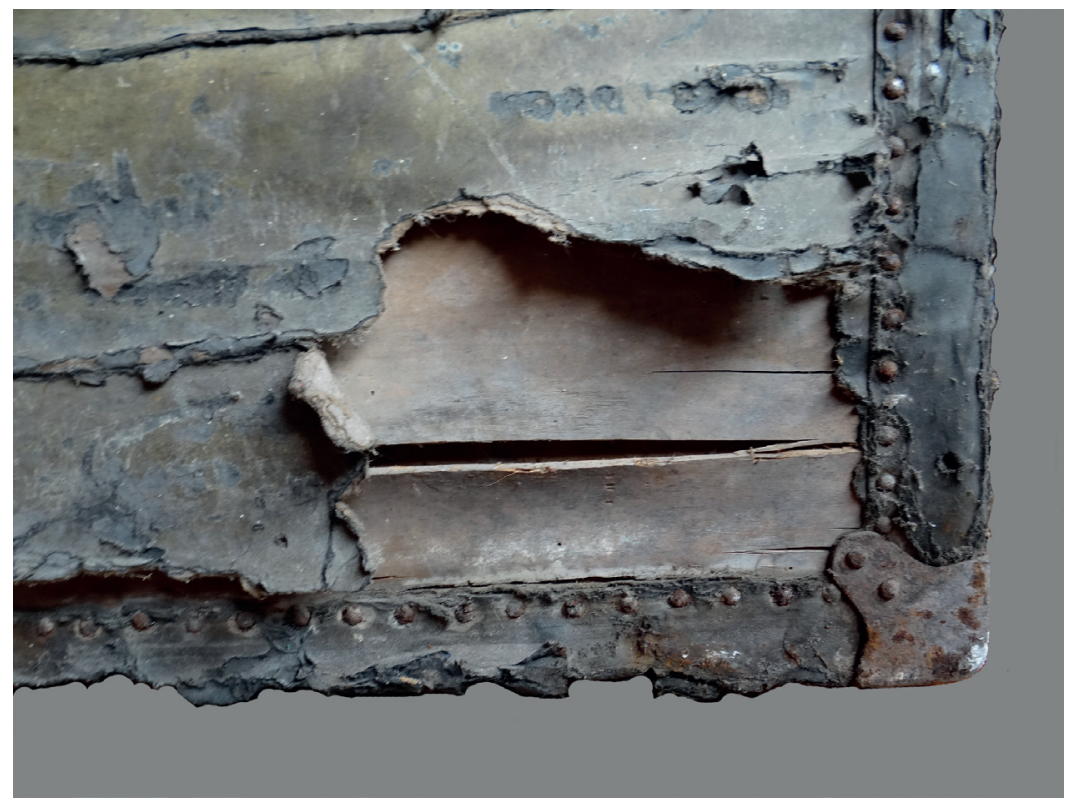

Ryc. 9. Zbliżenie na tył kufra (fot. D. Kobiałka).

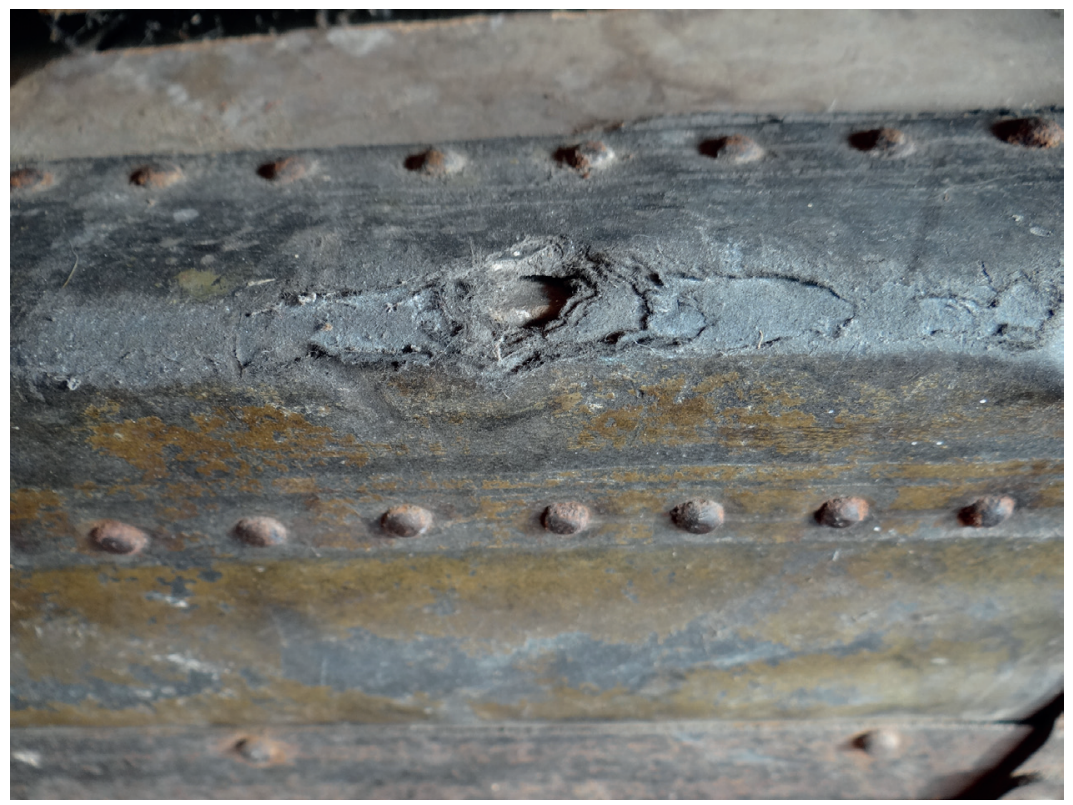

Ryc. 10. „Materialna pamięć” kufra (fot. D. Kobiałka). 


\section{OChrona DZIEDZICTWA? Nie, DZIĘKUJE}

Omawiany kufer to przykład - używając pojęcia R. Harrisona (2013) - „nieoficjalnego dziedzictwa" (unofficial heritage), to znaczy, dziedzictwa, które nie jest wpisane do oficjalnych rejestrów zabytków. Taka sytuacja pozwala wyjść poza pewne utarte klisze dotyczące refleksji nad rolą, znaczeniem pozostałości $\mathrm{z}$ dawnej i niedawnej przeszłości.

O dziedzictwie zwykle myśli się poprzez pryzmat jego ochrony i zarządzania (Smith 2006; Harrison 2013; por. również Kajda, Kostyrko 2016). Na uniwersytetach prowadzi się zajęcia, studia podyplomowe, które już w tytułach mają słowa klucze: ochrona, zarządzanie, dziedzictwo ${ }^{3}$. Jednak ochrona i zarządzanie to jedynie pewne opcje traktowania materialnych pozostałości przeszłości. Coraz więcej badaczy krytycznie podchodzi do nich jako upraszczających i determinujących ramy interpretacyjne (np. Chaoy 2001; Fojut 2009; Holtorf, Fairclough 2013). Reperkusją zachodzących zmian są m.in. narodziny nowej dyscypliny badań naukowych: krytycznych studiów nad dziedzictwem (critical heritage studies). Powstają także interdyscyplinarne czasopisma starające się być platformą dynamicznie zachodzących zmian w jego rozumieniu. W tym miejscu należy wspomnieć o International Journal of Heritage Studies ${ }^{4}$.

Ochrona i zarządzanie dziedzictwem w wielu przypadkach sprowadza się do prób zachowania danego artefaktu, krajobrazu czy też praktyki dla przyszłych pokoleń. Coś, co powstało w konkretnym czasie i miejscu próbuje się zmienić w coś ,atemporalnego", wyrwanego ze specyficznego kontekstu. Próby ochrony materialnej przeszłości to czasem działania zmierzające właśnie do zamazywania jej „,czasowego” wymiaru. Niemniej jednak należy wyraźnie podkreślić, iż przede wszystkim ,[...] rzeczy z przeszłości trwają tak długo jak ulegają transformacjom" (Olsen i in. 2012: 135; thumaczenie autora). Dążenie do zachowania dziedzictwa dla przyszłości to czasem zamazywanie śladów ich „multitemporalnych dziejów i wspomnień”. Jak twierdzą Bjørnar Olsen, Michael Shanks, Timothy Webmoor i Christopher Witmore (2012: 201; thumaczenie autora):

Kwestią bezdyskusyjną jest to, że wielu ludzi przejętych jest rzeczami z przeszłości, oraz, że wielu odczuwa silne przywiązanie do miejsc i monumentów, niemniej oczywistym jest, że to przywiązanie jest zaledwie asymetrycznym produktem emotywnych narracji i kulturowych przyzwyczajeń. Właściwie, to samo może dotyczyć przykładu „znaczących” miejsc, które wywołują swoje własne znaczenie. Rzeczy - monumenty, struktury topograficzne, krajobrazy kulturowe - mogą jawić się jako znaczące poprzez swoje własne unikalne, wyraźnie widoczne właściwości.

\footnotetext{
${ }^{3}$ Por. http://www.nid.pl/pl/Informacje ogolne/Aktualnosci/news.php?ID=3030 (dostęp: 9.01.2017).

${ }^{4}$ Por. http://www.tandfonline.com/toc/rjhs20/current (dostęp: 9.01.2017).
} 
Niszczenie, rozkład dziedzictwa, jak już pisałem w kilku innych miejscach (np. Kobiałka 2014), są inherentnymi elementami jego powstawania. Słowem, niszczenie rzeczy jest $w$ istocie odsłanianiem ich afektywnych właściwości (por. DeSilvey 2006; González-Ruibal 2008; Holtorf 2015). Ryciny 11 i 12 ukazują ten ,estetyczny i afektywny wymiar istnienia” dziedzictwa.

Zatem można powiedzieć, iż o dziedzictwie należy myśleć jako o symetrycznym procesie, w którym biorą udział ludzie i rzeczy. Jest ono zawsze też osadzone w danym miejscu. Kufer jest tego dobrym przykładem, ma on kilka wymiarów. Jest częścią wielkiej historii o polskich chłopach emigrujących do Stanów Zjednoczonych za pracą. To opowieść o rodzinnej rozłące, długich podróżach ,za morze”, listach wysyłanych przez ocean, aż po niezwykle ciężką i trudną „harówkę” w kopalni. W biografii tej pojawiają się I i II wojna światowa, trauma związana z przesiedleniami w nieznane miejsca. To również część historii, biografii, dziedzictwa mojej rodzinny: lokalnej mikrohistorii (autobiografii), gdzie to, co przeszłe, jest częścią tego, co teraźniejsze i jest zorientowane ku przyszłości.

To zarazem historia - albo nawet właściwiej - archeologia konkretnej rzeczy, jej przemian, uszkodzeń, napraw, zarysowań, powolnego pokrywania patyną, licznych „materialnych wspomnien” utrwalonych na jej powierzchni, pęknięć kolejnych klepek, stałego gnicia, z którym wiąże się nieprzyjemny za-

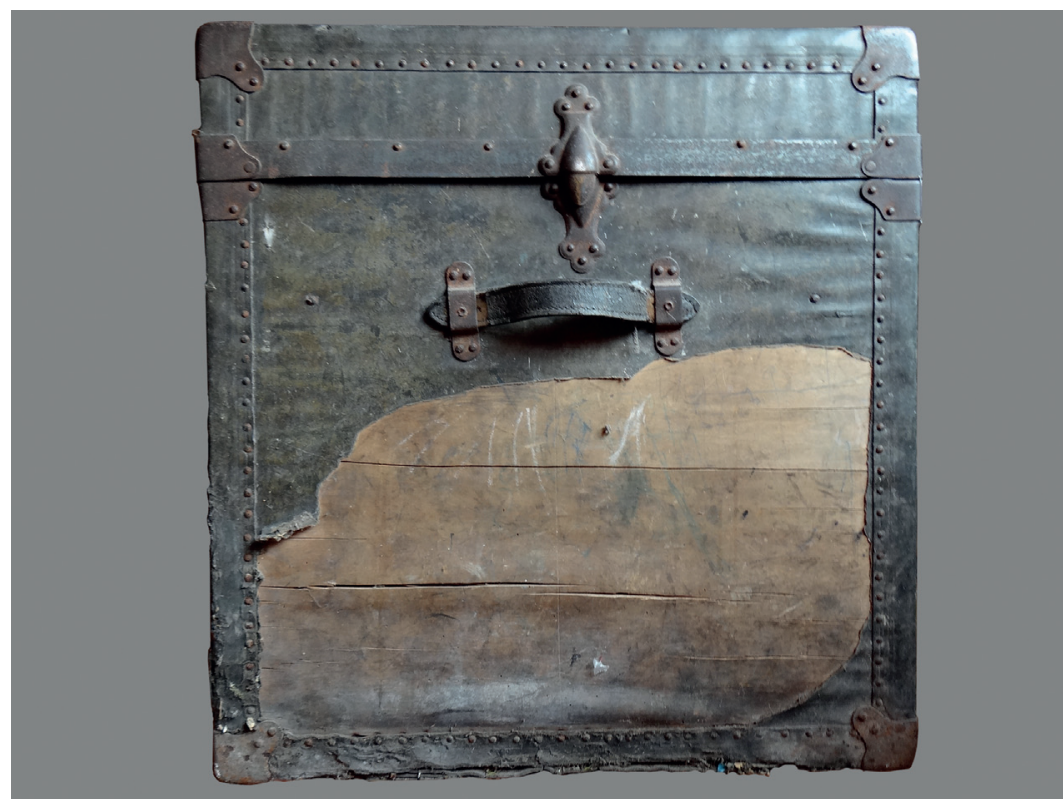

Ryc. 11. Afektywny wymiar dziedzictwa: stary kufer „musi” przeminąć, to część jest „bycia” (fot. D. Kobiałka). 


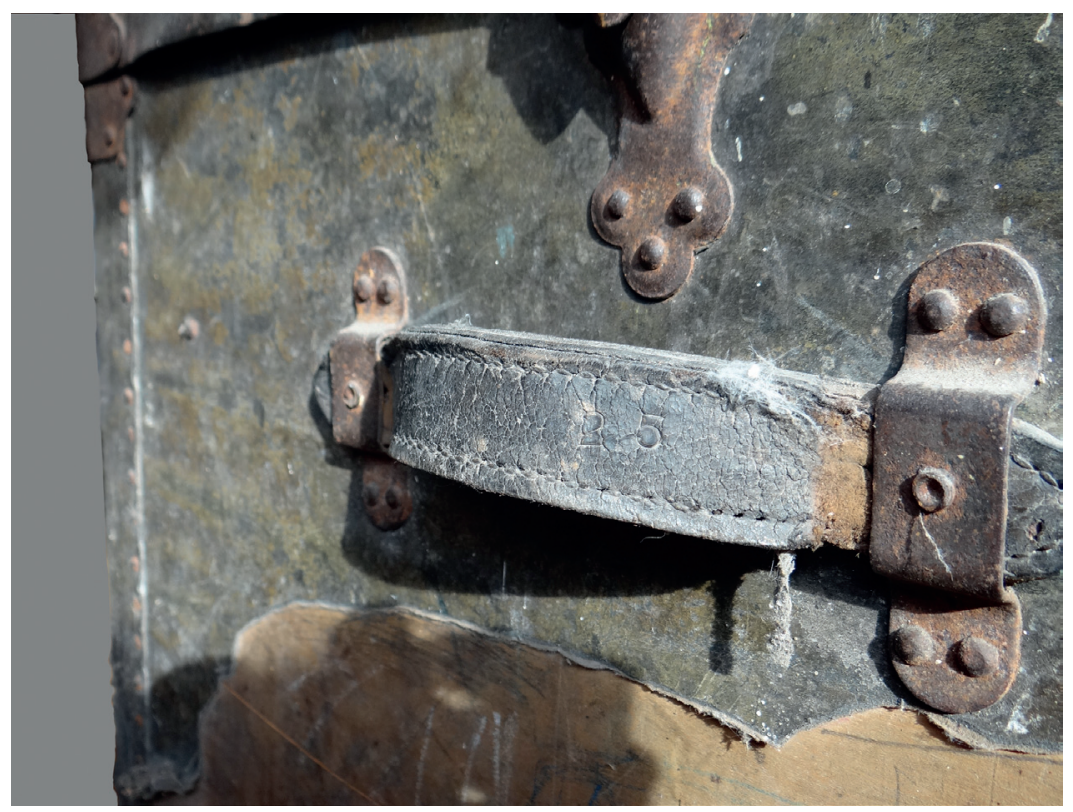

Ryc. 12. Renowacja zniszczonego kufra byłaby w rzeczywistości zniszczeniem wszystkich społecznych i materialnych wspomnień „zapamiętanych” (utrwalonych) na jego powierzchni (fot. D. Kobiałka).

pach wydobywający się z wnętrza kufra. To też dziesiątki kropel potu wylanych przez pradziadka przy transporcie tak dużej (wymiary: 101 x 62 x $61 \mathrm{~cm}$ ) i ciężkiej rzeczy, jaką jest kufer. Częścią jego biografii są również dziecięce zabawy, o których opowiadała mi moja mama etc. Tym wszystkim właśnie jest „kufer rozumiany jako dziedzictwo"; jako proces i forma relacji społeczno-materialnych. Dokładnie w takim kierunku idzie refleksja R. Harrisona (2013: 222; thumaczenie autora) nad nowym podejściem do dziedzictwa:

Dziedzictwo nie wyłania się jako proces dotyczący przeszłości i teraźniejszości, lecz jako zorientowane na przyszłość, nowopowstające, przypadkowe i kreatywne przedsięwzięcie. Nie jest to proces nadawania znaczenia, który istnieje jedynie w ludzkiej głowie, lecz proces, w który różni aktorzy, zarówno ludzcy jak i nie-ludzcy, są w równym stopniu wplątani, i który łączy je poprzez czas i miejsce [...]. [...]. Chodzi o rozumienie dziedzictwa nie jako dyskursu czy też procesu symbolicznego nadawania znaczeń, ale jako nowopowstających właściwości relacji między ludźmi i nie-ludźmi, w których to kreatywne działania 'rzeczy' są postrzegane jako istniejące w mieszanej lub podzielanej relacji symetrii z ludźmi. Rzeczy, które tworzą część kolekcji muzealnych przyjmują nowe formy znaczenia i sprawczości w ich trwających, kreatywnych relacjach z ludźmi w teraźniejszości. 


\section{Podsumowanie}

Kulturowa biografia rzeczy jako koncepcja teoretyczna służyła głównie archeologom do analizy zmiennych znaczeń i funkcji danych przedmiotów oraz krajobrazów na przestrzeni dziejów. Paradoksalnie, nie dotyczyła ona artefaktów i miejsc. Były one interesujące ze względu na przypisywane im znaczenia na osi czasu. Konsekwentnie, można powiedzieć, że takie podejście było „niesymetryczne”. Bardziej interesujące były funkcje i znaczenia przypisywane artefaktom niż one same. Taka postawa badawcza była w istocie „uciszaniem”, „udomowianiem” rzeczy w ich niezależnym i intymnym byciu „w czasie”. Tekst ten postulował bardziej symetryczne rozumienie dziedzictwa biorąc za studium przypadku dzieje pewnego kufra.

Teza, iż „wszyscy jesteśmy teraz archeologami” (Shanks 2012) daje możliwości poszerzenia obszaru refleksji nad niedawną przeszłością; może być pretekstem do uprawiania ,archeologii nas samych”. Tak było w przypadku tego tekstu: analizowany kufer został przywieziony ze Stanów Zjednoczonych przez mojego pradziadka. Od tego momentu, aż do chwili pisania tych słów, to jest 10 stycznia 2017 r., był on w taki czy inny sposób związany z moją rodziną. Opisana historia, jego biografia miała pokazać, iż dziedzictwo powstaje z relacji tego, co społeczne i tego, co materialne.

I na koniec, ostatnia uwaga $\mathrm{w}$ odniesieniu do współczesnego rozumienia dziedzictwa: pozwólmy rzeczom „być” a nie tylko „coś znaczyć”. Tak też postępowała z kufrem moja babcia. Nie traktowała ona tej rzeczy jak czegoś bezcennego, rodzinnego dziedzictwa, nośnika pamięci, czegoś co należy za wszelką cenę zachować dla potomnych, co należy „,chronić” i czym zarządzać. Wręcz przeciwnie, przez ponad 40 lat przedmiot stał w ciemnej, zawilgoconej piwnicy powoli ulegając fragmentaryzacji, gniciu i niszczeniu. Dlatego też jako kolejny właściciel kufra nie zamierzam go konserwować i poddawać renowacji. Idea jest taka żeby nadal „odsłaniał” on swoje multitemporalne, społeczne i materialne wspomnienia. Pozwolenie by dziedzictwo przeminęło we własnym, niepowtarzalnym tempie oznacza właśnie ,troskę o nie”. Chodzi o „[...] przyjęcie bardziej pokornej postawy wiedzy, troski i szacunku wobec tego czym są rzeczy w swoim własnym byciu" (Olsen i in. 2012: 203; thumaczenie autora). Podsumowując, czasem im mniej „ochrony i zarządzania dziedzictwem” tym lepiej dla niego samego. 


\section{PODZIĘKOWANIA}

W tym miejscu należą się specjalne podziękowania dla mojej babci Hanny Gostomskiej za niezwykłe rozmowy o jej życiu; w istocie to samo życie pisze najciekawsze historie (archeologie). Dziękuję za to, że jest.

Dawid Kobiałka

Instytut Archeologii i Etnologii PAN

e-mail: dawidkobialka@wp.pl

\section{Bibliografia}

Benjamin W. (1975), Twórca jako wytwórca: eseje i rozprawy, Wydawnictwo Poznańskie, Poznan.

Bjerck H.B. (2014), My father's things, [w:] B. Olsen, P. Pétursdóttir (red.), Ruin memories: materialities, aesthetics and the archaeology of the recent past, Routledge, Abingdon-New York, s. 109-127.

Buchli V., Lucas G. (red.) (2001), Archaeologies of the contemporary past, Routledge, London-New York.

Choay F. (2001), The invention of the historic monument, Cambridge University Press, Cambridge.

Darvill T. (2006), Stonehenge. The biography of a landscape, Tempus, Stroud.

DeSilvey C. (2006), Observed decay: Telling stores with mutable things, „Journal of Material Culture" t. 11(3), s. 318-338.

Domańska E. (1999), Mikrohistorie: Spotkania w międzyświatach, Wydawnictwo Poznańskie, Poznań.

Domańska E. (2006), Historie niekonwencjonalne. Refleksja o przeszlości w nowej humanistyce, Wydawnictwo Poznańskie, Poznan.

Fojut N. (2009), The philosophical, political and pragmatic roots of the conservation, [w:] Heritage and beyond, Council of Europe, Strasbourg, s. 13-22, https:// www.coe.int/t/dg4/cultureheritage/heritage/identities/PatrimoineBD_en.pdf (dostęp: 9.01.2017).

Głosek M. (red.) (2010), Nekropolia z terenu bytego poligonu wojskowego na Brusie $w$ Łodzi. Mogiła ekshumowana w 2008 roku, Uniwersytet Łódzki, Łódź.

González-Ruibal A. (2008), Time to destroy. An archaeology of supermodernity, „Current Anthropology", t. 49(2), s. 247-279.

González-Ruibal A. (2014), Archaeology of the contemporary past, [w:] C. Smith (red.), Encyclopedia of global archaeology, Springer, New York, s. 1683-1694.

Gould R.A., Schiffer M.B. (red.) (1981), Modern material culture: The archaeology of us, Academic, New York.

Harrison R. (2013), Heritage: Critical approaches, Routledge, Abingdon-New York.

Holtorf C. (2002), Notes on the life history of a pot sherd, „Journal of Material Culture”, t. 7(1), s. 49-71. 
Holtorf C. (2005), From Stonehenge to Las Vegas, Altamira Press, Lanham, MD.

Holtorf C. (2014), Time for archaeology! A personal portfolio of fieldwork, [w:] H. Alexandersson, A. Andreeff, A. Bünz (red.), Med hjärta och hjärna: En vänbok till professor Elisabeth Arwill-Nordbladh, Universtity of Göteborg, Göteborg, s. 51-64.

Holtorf C. (2015), Averting loss aversion in cultural heritage, „International Journal of Heritage Studies", t. 21(4), s. 405-421.

Holtorf C., Fairclough G. (2013), The New Heritage and re-shaping of the past, [w:] A. González-Ruibal (red.), Reclaiming archaeology. Beyond the tropes of modernity, Routledge, London, s. 197-210.

Holtorf C., Piccini A. (red.) (2009), Contemporary archaeologies - excavating now, Peter Lang, Frankfurt am Main.

Jones A. (2002), Archaeological theory and scientific practice, Cambridge University Press, Cambridge.

Kajda K., Kostyrko M. (2016), Contemporary dimension of heritage promotion - towards socially engaged archaeology, „Sprawozdania Archeologiczne”, t. 68, s. 9-23.

Kobiałka D. (2008), Z życia dwóch naszyjników. Problemy biograficznego podejścia do rzeczy, „Kultura Współczesna”, t. 57(3), s. 201-216.

Kobiałka D. (2014), Let heritage die! The ruins of trams at depot no. 5 in Wrocław, Poland, „Journal of Contemporary Archaeology”, t. 1(2), s. 351-368.

Kobiałka D. (2015), Biografia rzeczy jako sposób interpretowania roli i znaczenia dziedzictwa, [w:] M. Kępski (red.), Z rzeka w tle. Biografia Śluzy Katedralnej/Framed by the River. The Biography of the Cathedral Lock, Centrum Turystyki Kulturowej Trakt, Poznań, s. 44-49.

Kobiałka D., Frąckowiak M., Kajda K. (2015), Tree memories of the Second World War: a case study of common beeches from Chycina, Poland, „Antiquity”, t. 89(345), s. 683-696.

Kobyliński Z. (2014), Krajobraz i pamięć, [w:] J. Wysocki (red.), Archaeologica Hereditas. Konserwacja zapobiegawcza środowiska 2. Krajobraz kulturowy, Wydawnictwo Fundacji Archeologicznej, Warszawa-Zielona Góra, s. 13-22.

Kola A. (2000), Hitlerowski obóz zagłady Żydów w Betżcu w świetle źródeł archeologicznych: badania 1997-1999, Rada Ochrony Pamięci Walk i Męczeństwa, United States Holocaust Memorial Museum, Warszawa-Waszyngton.

Kopytoff I. (2005), Kulturowa biografia rzeczy. Utowarowienie jako proces, [w:] M. Kempny, E. Nowicka (red.), Badanie kultury. Elementy teorii antropologicznej. Kontynuacje, Wydawnictwo Naukowe PWN, Warszawa, s. 249-274.

Ławrynowicz O., Żelazko J. (red.) (2015), Archeologia totalitaryzmu. Ślady represji 1939-1956, Instytut Archeologii Uniwersytetu Łódzkiego, Instytut Pamięci Narodowej Komisja Ścigania Zbrodni przeciwko Narodowi Polskiemu Oddział w Łodzi, Łódź.

Moshenska, G. (2013), The archaeology of the Second World War: Uncovering Britain's wartime heritage, Pen \& Sword Archaeology, Barnsley, UK.

Olivier L. (2011), The dark abyss of time: archaeology and memory, Altamira Press, Lanham, MD. 
Olsen B., Shanks M., Webmoor T., Witmore C. (2012), Archaeology: The discipline of things, University of California Press, Berkeley-Los Angeles-London.

Olsen B, Pétursdóttir P. (red.) (2014), Ruin memories: Materialities, aesthetics and the archaeology of the recent past, Routledge, Abingdon-New York.

Prinke A. (1973), Możliwości porównawczego stosowania danych etnograficznych $w$ archeologii, „Etnografia Polska”, t. 17, s. 41-66.

Roymans N. (1995), The cultural biography of urnfields and the long-term history of a mythical landscape (with comments and reply), „Archaeological Dialogues”, t. 2(1), s. 2-38.

Saunders N. (2007), Killing time: Archaeology and the First World War, Stroud, Sutton.

Shanks M. (1998), The life of an artifact in an interpretive archaeology, „Fennoscandia Archaeologica", t. 15, s. 15-30.

Shanks M. (2012), The archaeological imagination, Left Coast Press, Walnut Creek, CA.

Smith L. (2006), The uses of heritage, Routledge, London-New York.

Thomas J. (2004), Archaeology and modernity, Routledge, New York.

Trigger B. (2006), A history of archaeological thought, second edition, Cambridge University Press, Cambridge.

Ulin J. (2009), Into the space of the past: A family archaeology, [w:] C. Holtorf, A. Piccini (red.), Contemporary archaeology - excavating now, Peter Lang, Frankfurt and Main, s. 145-160.

Zalewska A. (red.) (2016), Archeologia współczesności, SNAP, Warszawa.

\section{SUMMARY}

\section{A TRUNK FULL OF MEMORIES: AN (AUTO)BIOGRAPHICAL APPROACH TO HERITAGE}

This paper analyses the so-called biography of a thing as a way of thinking about the value and meaning of heritage. A certain, almost 100 years old, trunk is used as a case study to present how heritage is constituted trough relations between people, things, and places. Indeed, heritage is a kind of relation between humans and non-humans. To back up this thesis, this article offers a five-step approach.

First, the starting point is Michael Shanks' thesis that "we are all archaeologists now". The British archaeologist - it can be said - argues for broadening the archaeological discourse and to look archaeologically at the world we all live in. From this point of view, a Neolithic pot sherd and a contemporary thing such as a trunk, for example, represent the same category of an archaeological artefact. Through their materiality, they both might be objects of an archaeological scrutiny.

Second, I shortly discuss the archaeological research on the recent past. Archaeology is a practice anchored here and now. One of the archaeological perspectives that 
analyses the relics of the recent past is the approach where archaeologists study their own heritage i.e. the histories of their own families. This is the perspective developed further in this paper.

Third, it is argued that the theoretical concept known as biography of a thing, can be useful in the context of the archaeology of the recent past. It is the concept that takes into account the past and present of each artefact, landscape or practice. This approach allows for studying both the social and the material memories which are crucial apropos of the archaeological research on the recent past. Here, archaeologists take into account things as well as people's memories about them.

Fourth, an analysis of a trunk which the author found in the grandmother's basement is used as a case study to present the potential of the archaeological research on the recent past. Some episodes of the biography of a trunk are highlighted to claim that heritage is constituted through different kinds of relations between many agents, both humans and non-humans.

And the last point, the trunk is a good example that shows the limitations of archaeological thinking about heritage through the lens of its preservation and management. Indeed, the crucial conclusion of this article is that, sometimes, the less preservation and management of (archaeological) heritage the better for heritage itself. In other words, destruction and decay of heritage are the very part of its biography. 